\title{
Analisis Daya Dukung Pondasi Bored Pile pada Proyek Pembangunan Menara Listrik Transmisi 500 KV Peranap-Perawang
}

\author{
Andre Chandra ${ }^{1}$, Gusneli Yanti ${ }^{2}$, Shanti Wahyuni Megasari ${ }^{3}$. \\ Program Studi Teknik Sipil, Fakultas Teknik, Universitas Lancang Kuning \\ Jl. Yos Sudarso km. 8 Rumbai, Pekanbaru, Telp. (0761) 52324 \\ Email: andrechandra07@yahoo.com, gusneli@unilak.ac.id, shanti@unilak.ac.id
}

\begin{abstract}
ABSTRAK
Pondasi bored pile berinteraksi dengan tanah untuk menghasilkan daya dukung yang mampu memikul dan memberikan keamanan pada struktur atas, dimana terjadi perubahan jenis pondasi dalam proyek pembangunan menara transmisi $500 \mathrm{kV}$. Tujuan penelitian ini adalah untuk mengetahui daya dukung pondasi bored pile menara transmisi 500 $\mathrm{kV}$. Metode yang digunakan adalah metode Aoki dan de Alencar, metode Schmertmann dan Nottingham, metode Meyerhoff, dan metode Guy Sangrelatt. Selanjutnya, dikarenakan bored pile-nya adalah kelompok tiang, maka digunakan pula dua jenis metode efisiensi kelompok tiang, yaitu metode Converse-Labarre dan metode Los Angeles Group. Dari hasil perhitungan diperoleh bahwa untuk pondasi bored pile dengan jumlah 16 tiang, kedalaman 6 meter dan diameter tiang sebesar $40 \mathrm{~cm}$, diperoleh nilai daya dukung pondasi ultimit bored pile yang paling minimum adalah sebesar 1487,845 kN untuk menahan beban compression terfaktor menara sebesar 644,072 kN kondisi normal. Sementara untuk daya dukung ijin tarik pondasi bored pile, diperoleh nilai sebesar 240,562 kN, tidak mencukupi untuk menahan beban uplift terfaktor menara sebesar 479,497 kN. Untuk mengatasinya, maka diperlukan penambahan jumlah tiang menjadi 25 buah dan menambah kedalaman menjadi 7,6 meter, sehingga diperoleh nilai daya dukung ijin tarik sebesar 490,399 kN, yang dapat menambah daya dukung pondasi bored pile.
\end{abstract}

Kata Kunci: bored pile, daya dukung, kelompok tiang, sondir

\begin{abstract}
Bored pile foundation interacted with soil to makes a bearing capacity which capable of carrying and providing security in upper structure, to solve the foundation type changed design of $500 \mathrm{kV}$ transmission tower. The purpose is to knowing the bearing capacity of bored pile foundation on it. Methods to analyze are Aoki and de Alencar, Schmertmann and Nottingham, Meyerhoff, and Guy Sangrelatt method. Because the pile are in groups, they are necessary to calculate the efficiency of pile group, so it using two methods of efficiency, like Converse-Labarre and Los Angeles Group methods. Results of the calculation, the ultimate bearing capacity value of 16 piles, 6 meters depth, and 40 centimeters' diameter of bored pile is amount 1487,845 $\mathrm{kN}$ at the least to hold the tower's factored compression load amount 644,072 $\mathrm{kN}$ in normal condition. Than, the pull bearing capacity is amount 240,562 $\mathrm{kN}$. That can't be enough to hold the tower's factored uplift load amount 479,497 kN. The solve is making addition by the number of piles become 25 units, and add depth become 7,6 meter, so obtained the value of pull bearing capacity amount 490,399 kN, and it's can be add the bored pile's bearing capacity.
\end{abstract}

Keywords: bored pile, bearing capacity, pile groups, sondir

\section{PENDAHULUAN}

Dalam pembangunannya, transmisi listrik memiliki beberapa menara penghubung yang dibangun sesuai dengan ketinggian tertentu pada beberapa titik yang sudah ditentukan. Dalam pembangunan menara listrik, tahapan yang cukup penting adalah perencanaan pondasinya. Menara listrik dapat menggunakan pondasi dangkal maupun pondasi dalam sesuai dengan kondisi tanah di lokasi pembangunan. Baik pondasi dangkal maupun pondasi dalam, mengharuskan untuk melakukan penyelidikan tanah melalui beberapa metode yang umum dilaksanakan di setiap tahapan pembangunan pondasi.
Pondasi bored pile dipakai apabila tanah dasar yang kokoh yang mempunyai daya dukung besar terletak sangat dalam, yaitu kurang lebih $15 \mathrm{~m}$. Bored pile berinteraksi dengan tanah untuk menghasilkan kuat dukung yang mampu memikul dan memberikan keamanan pada struktur atas. Perencanaan pondasi bored pile mencakup rangkaian kegiatan yang dilaksanakan dengan berbagai tahapan yang meliputi studi kelayakan dan perencanaan teknis. Semua ini dilakukan supaya menjamin hasil akhir suatu konstruksi yang kuat, aman, serta ekonomis.

Untuk menghasilkan kuat dukung yang akurat maka diperlukan suatu penyelidikan tanah yang akurat juga. 
Penyelidikan tanah yang umum digunakan dalam proyek pembangunan ada 2 macam, diantaranya melalui uji sondir atau Cone Penetration Test (CPT) dan Standard Penetration Test (SPT). Karena terbatasnya cara pengujian dilapangan, maka hanya digunakan uji sondir (CPT) untuk penyelidikan tanah yang bertujuan mengetahui perlawanan penetrasi konus dan hambatan lekat tanah yang merupakan indikasi dari kekuatan dukung lapisan tanah dengan menggunakan rumus empiris.

Adapun tujuan dari penelitian ini adalah untuk mengetahui daya dukung pondasi bored pile.

\section{METODE PENELITIAN}

Untuk menganalisis daya dukung pondasi bored pile pada proyek pembangunan Menara Transmisi Listrik 500 $\mathrm{kV}$ ini yang terletak di Kecamatan Pangkalan Lesung, Kabupaten Pelalawan, penulis memperoleh data antara lain dari kontraktor PT. Waskita Karya diperoleh berupa data hasil sondir, dan data pembebanan.

\section{Data Perencanaan Teknis dan Pembebanan Menara}

Data teknis bored pile yang akan dianalisis seperti pada Tabel 1 di bawah ini:

Tabel 1. Data Perencanaan Teknis Bored Pile

\begin{tabular}{|c|l|l|}
\hline No & \multicolumn{1}{|c|}{ Jenis } & \multicolumn{1}{c|}{ Keterangan } \\
\hline 1 & Panjang bored pile & $600 \mathrm{~cm}$ \\
\hline 2 & Diameter bored pile & $\varnothing 40 \mathrm{~cm}$ \\
\hline 3 & Jumlah pile & $4 \times 4=16$ buah \\
\hline
\end{tabular}

(Sumber: Analisis, 2018)

Data pembebanan menara seperti seperti pada Tabel 2 dan Gambar 1.

Tabel 2. Data Beban Maksimum Struktur Menara Tipe 4AA+12

\begin{tabular}{|c|c|c|c|c|c|}
\hline $\begin{array}{c}\text { Tipe } \\
\text { Pembeban } \\
\text { an*) }\end{array}$ & $\begin{array}{l}\text { Kond } \\
\text { isi }\end{array}$ & $\begin{array}{c}\text { Support } \\
\text { Reaction } \\
\text { (Max) }\end{array}$ & $\begin{array}{c}\text { Force } \\
-X \\
(\mathrm{kN})\end{array}$ & $\begin{array}{l}\text { Forc } \\
e-Y \\
(\mathrm{kN})\end{array}$ & $\begin{array}{l}\text { Forc } \\
e-Z \\
(\mathrm{kN})\end{array}$ \\
\hline \multirow{4}{*}{ Vertical } & \multirow{2}{*}{$\begin{array}{l}\text { Nor- } \\
\text { mal }\end{array}$} & $\begin{array}{l}\text { Compres } \\
\text { sion }\end{array}$ & $\begin{array}{c}2604, \\
523\end{array}$ & $\begin{array}{c}526,4 \\
60\end{array}$ & $\begin{array}{c}536,7 \\
27\end{array}$ \\
\hline & & Uplift & $\begin{array}{c}1884, \\
298\end{array}$ & $\begin{array}{c}396,2 \\
70\end{array}$ & $\begin{array}{c}399,5 \\
81\end{array}$ \\
\hline & \multirow{2}{*}{$\begin{array}{c}\text { Bro- } \\
\text { ken }\end{array}$} & $\begin{array}{l}\text { Compres } \\
\text { sion }\end{array}$ & $\begin{array}{c}1961, \\
082\end{array}$ & $\begin{array}{c}361,7 \\
48\end{array}$ & $\begin{array}{c}424,3 \\
13\end{array}$ \\
\hline & & Uplift & $\begin{array}{c}1227, \\
741\end{array}$ & $\begin{array}{c}224,2 \\
27\end{array}$ & $\begin{array}{c}282,4 \\
35\end{array}$ \\
\hline
\end{tabular}

*) Tidak termasuk faktor beban overload $(1,2)$

(Sumber : PT. Bukaka Teknik Utama, 2016)

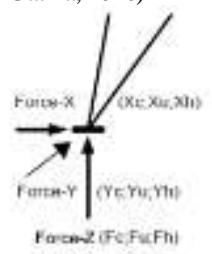

Gambar 1. Support Reaction 500 kV 4-Circuit Suspension Tower $4 A A$

(Sumber : PT. Bukaka Teknik Utama, 2016)

\section{Data Sondir}

Data sondir yang dilakukan pada lokasi penelitian akan digunakan untuk analisa daya dukung pondasi bored pile menara listrik transmisi $500 \mathrm{kV}$, yaitu pada titik PP157, seperti pada Gambar 2.

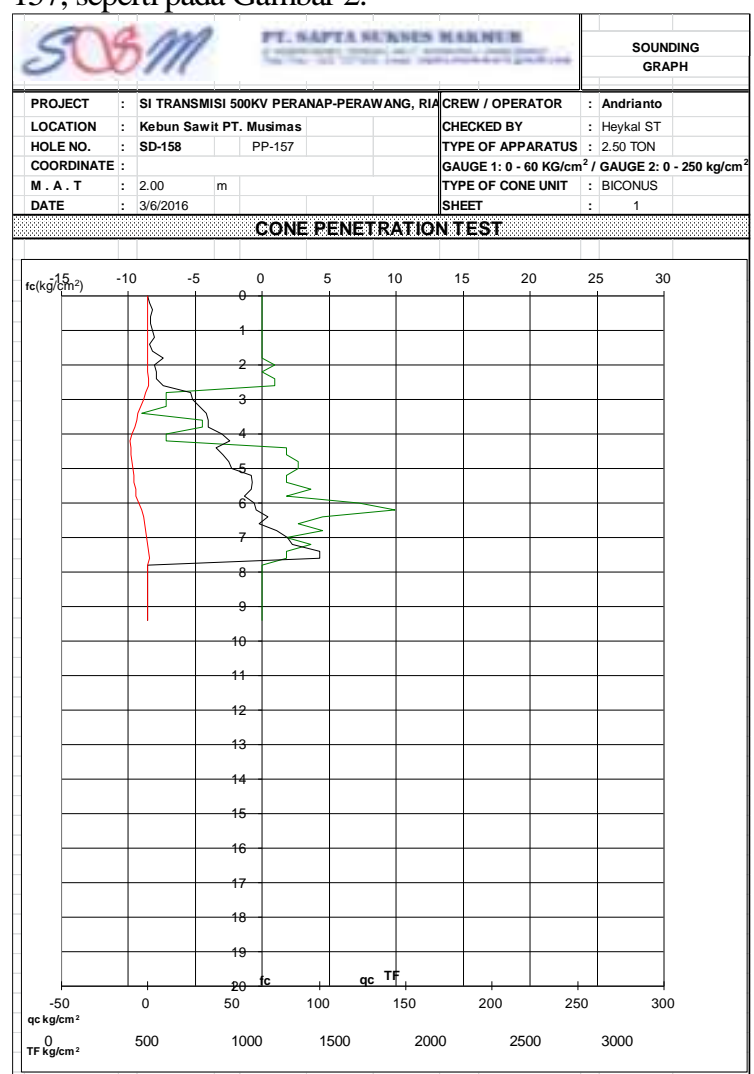

Gambar 2. Grafik Sondir Lokasi Proyek di Titik PP-157 (Sumber : PT. Waskita Karya, 2016)

\section{Metode Analisis}

Dalam perhitungan perencanaan pondasi tiang ini, penulis melakukan analisis perhitungan daya dukung pondasi bored pile menggunakan metode-metode yang akan dijelaskan kemudian, dan menyimpulkan hasilnya. Adapun langkah perhitungan yang akan digunakan untuk analisis daya dukung pondasi bored pile menggunakan data sondir diantaranya yaitu Metode Aoki dan De Alencar, Metode Schmertmann dan Nottingham, Metode Meyerhoff, dan Metode Guy Sangrelatt.

\section{Metode Aoki dan de Alencar}

Aoki dan de Alencar mendefinisikan kuat dukung ultimit pondasi bored pile yang dinyatakan dengan rumus:

$$
\mathrm{Q}_{\mathrm{u}}=\mathrm{q}_{\mathrm{b}} \times \mathrm{A}_{\mathrm{b}}
$$

Keterangan :

$\mathrm{Q}_{\mathrm{u}}=$ Kapasitas daya dukung bored pile $(\mathrm{kN})$

$\mathrm{q}_{\mathrm{b}}=$ Tahanan ujung sondir $\left(\mathrm{kN} / \mathrm{m}^{2}\right)$

$\mathrm{A}_{\mathrm{b}}=$ Luas penampang tiang $\left(\mathrm{m}^{2}\right)$

Aoki dan de Alencar mengusulkan untuk memperkirakan kapasitas dukung ultimit dari data sondir. Kapasitas dukung ujung persatuan luas (qb) diperoleh sebagai berikut:

$$
\mathrm{q}_{\mathrm{b}}=\frac{\mathrm{q}_{\mathrm{ca}}(\text { base })}{\mathrm{F}_{\mathrm{b}}}
$$

Keterangan :

$\mathrm{q}_{\mathrm{ca}}($ base $)=$ Perlawanan konus rata-rata 1,5 D diatas ujung 
tiang, 1,5 D di bawah ujung tiang

$\mathrm{F}_{\mathrm{b}} \quad=$ Faktor empirik yang tergantung pada tipe tiang pancang

\section{Metode Schmertmann dan Nottingham}

Berbeda dengan Aoki dan de Alencar, Schmertmann dan Nottingham merumuskan kuat dukung ultimit neto $(\mathrm{Qu})$, yang dihitung dengan persamaan :

$$
Q_{u}=A_{b} f_{b}+A_{s} f_{s}
$$

$$
\text { atau } \mathrm{Q}_{\mathrm{u}}=\mathrm{A}_{\mathrm{b}} \omega \mathrm{q}_{\mathrm{ca}}+\mathrm{A}_{\mathrm{s}} \mathrm{K}_{\mathrm{f}} \mathrm{q}_{\mathrm{f}}
$$

Keterangan :

$\mathrm{A}_{\mathrm{b}} \quad=$ Luas penampang tiang $\left(\mathrm{cm}^{2}\right)$

$\mathrm{A}_{\mathrm{s}} \quad=$ Luas selimut tiang $\left(\mathrm{cm}^{2}\right)$

$\mathrm{f}_{\mathrm{b}} \quad=$ Tahanan ujung satuan $\left(\mathrm{kg} / \mathrm{cm}^{2}\right)$

$\mathrm{f}_{\mathrm{s}} \quad=$ Tahanan gesek satuan $\left(\mathrm{kg} / \mathrm{cm}^{2}\right)$

$\mathrm{q}_{\mathrm{ca}}=$ Tahanan konus rata-rata $\left(\mathrm{kg} / \mathrm{cm}^{2}\right)$

$\mathrm{q}_{\mathrm{f}} \quad=$ Tahanan gesek sisi konus $\left(\mathrm{kg} / \mathrm{cm}^{2}\right)$

$\mathrm{K}_{\mathrm{f}} \quad=$ Koefisien tak berdimensi

$\omega=$ Koefisien korelasi

Dalam metode Schmertmann dan Nottingham (1975) tahanan ujung tiang per satuan luas, diperoleh dari nilai rata-rata qc disepanjang $8 \mathrm{~d}$ diatas dasar tiang sampai $0,7 \mathrm{~d}$ atau $4 \mathrm{~d}$ di bawah tiang.

\section{Metode Meyerhoff}

Sama halnya seperti Metode Schmertmann dan Nottingham, perhitungan daya dukung pondasi bored pile oleh Metode Meyerhoff juga memperhitungkan tahanan ujung dan tahanan gesek. Berikut adalah langkah perhitungannya:

$$
f_{b}=\omega_{1} \omega_{2} q_{c a}
$$

Keterangan :

$\mathrm{f}_{\mathrm{b}} \quad=$ Tahanan ujung satuan, untuk tiang bor diambil $70 \%$ atau $50 \%$-nya $\left(\mathrm{kg} / \mathrm{cm}^{2}\right)$

$\mathrm{q}_{\mathrm{ca}}=\mathrm{q}_{\mathrm{c}}$ rata-rata $\left(\mathrm{kN} / \mathrm{m}^{2}\right)$ pada zona 1d di bawah ujung tiang dan $4 \mathrm{~d}$ di atasnya

$\omega_{1}=[(\mathrm{d}+0,5) / 2 \mathrm{~d}]^{\mathrm{n}} ;$ koefisien modifikasi pengaruh skala, jika d $>0,5 \mathrm{~m} \omega_{1}=1$

$\omega_{2}=\mathrm{L} / 10 \mathrm{~d}$; koefisien modifikasi untuk penetrasi tiang dalam lapisan pasir padat saat $\mathrm{L}<10 \mathrm{~d}$, Jika $\mathrm{L}>10 \mathrm{~d}, \omega_{2}=1$

$\mathrm{d} \quad=$ Diameter tiang $(\mathrm{m})$

$\mathrm{L} \quad=$ Kedalaman penetrasi tiang di dalam lapisan pasir padat $(\mathrm{m})$

$\mathrm{N}=$ Nilai eksponensial [ (1 untuk pasir longgar $\left(\mathrm{q}_{\mathrm{c}}\right.$ $<5 \mathrm{MPa}$ ), (2 untuk pasir kepadatan sedang (5 $\left.\mathrm{MPa}<\mathrm{q}_{\mathrm{c}}<12 \mathrm{MPa}\right),\left(3\right.$ untuk pasir padat $\left(\mathrm{q}_{\mathrm{c}}\right.$ $>12 \mathrm{MPa})]$

Untuk tiang pancang, tahanan gesek satuan diambil salah satu dari:

$$
\mathrm{f}_{\mathrm{s}}=\mathrm{K}_{\mathrm{f}} \mathrm{q}_{\mathrm{f}} \text { dengan } \mathrm{K}_{\mathrm{f}}=1
$$
sisi konus :

atau, bila tidak dilakukan pengukuran tahanan gesek

$$
\mathrm{f}_{\mathrm{s}}=\mathrm{K}_{\mathrm{c}} \mathrm{q}_{\mathrm{c}} \text { dengan } \mathrm{K}_{\mathrm{c}}=0,005
$$

Keterangan :

$\mathrm{f}_{\mathrm{s}} \quad=$ Tahanan gesek satuan $\left(\mathrm{kg} / \mathrm{cm}^{2}\right)$

$\mathrm{K}_{\mathrm{f}} \quad=$ Koefisien modifikasi tahanan gesek sisi konus
$\mathrm{K}_{\mathrm{c}} \quad=$ Koefisien modifikasi tahanan konus

Untuk tiang bor, Meyerhoff menyarankan menggunakan faktor reduksi $70 \%$ dan $50 \%$ dalam menghitung tahanan gesek tiang dengan menggunakan persamaan (6) dan (7).

\section{Metode Guy Sangrelatt}

Pamungkas A, dan Harianti, E (2013) memperhitungkan daya dukung pondasi bored pile berdasarkan data sondir dengan meninjau terhadap daya dukung ijin tekan serta daya dukung ijin tarik tiang, seperti yang digunakan oleh Guy Sangrelatt.

Analisis daya dukung ijin tekan pondasi tiang terhadap kekuatan tanah mempergunakan formula sebagai berikut:

$$
\mathrm{P}_{\mathrm{a}}=\frac{\mathrm{q}_{\mathrm{c}} \times A_{\mathrm{P}}}{\mathrm{FK} 1}+\frac{\mathrm{T}_{\mathrm{F}} \times \mathrm{A}_{\mathrm{st}}}{\mathrm{FK} 2}
$$

Keterangan :

$\mathrm{P}_{\mathrm{a}} \quad=$ Daya dukung ijin tekan tiang $(\mathrm{kg})$

$\mathrm{q}_{\mathrm{c}} \quad=$ Tahanan ujung konus sondir $\left(\mathrm{kg} / \mathrm{cm}^{2}\right)$

$\mathrm{A}_{\mathrm{p}} \quad=$ Luas penampang tiang $\left(\mathrm{cm}^{2}\right)$

$\mathrm{A}_{\mathrm{st}} \quad=$ Keliling penampang tiang $(\mathrm{cm})$

$\mathrm{T}_{\mathrm{f}} \quad=$ Total friksi atau jumlah hambatan pelekat $(\mathrm{kg} / \mathrm{cm})$

FK1, FK2= Faktor keamanan, 3 dan 5

Analisis daya dukung ijin tekan pondasi tiang terhadap kekuatan tanah mempergunakan formula sebagai berikut:

$$
\mathrm{P}_{\mathrm{ta}}=\frac{\mathrm{T}_{\mathrm{f}} \times \mathrm{A}_{\mathrm{st}}}{\mathrm{FK} 2}+\mathrm{W}_{\mathrm{P}}
$$

Keterangan :

$\mathrm{P}_{\mathrm{ta}} \quad=$ Daya dukung ijin tarik tiang $(\mathrm{kg})$

$\mathrm{W}_{\mathrm{P}} \quad=$ Berat pondasi $(\mathrm{kg})$

$\mathrm{A}_{\mathrm{st}} \quad=$ Keliling penampang tiang $(\mathrm{cm})$

$\mathrm{T}_{\mathrm{f}} \quad=$ Total friksi atau jumlah hambatan pelekat $(\mathrm{kg} / \mathrm{cm})$

FK2 = Faktor keamanan, 5

\section{Efisiensi Kelompok Tiang}

Kapasitas daya dukung tiang pancang kelompok dihitung berdasarkan faktor efisiensi, yaitu menggunakan Metode Converse-Labarre dan Los Angeles Group.

\section{Metode Converse-Labarre}

$$
\eta=1-\theta\left[\frac{(\mathrm{n}-1) \mathrm{m}+(\mathrm{m}-1) \mathrm{n}}{90 . \mathrm{m} \cdot \mathrm{n}}\right]
$$

Keterangan

$$
\begin{array}{ll}
\eta & =\text { Efisiensi kelompok tiang } \\
\mathrm{m} & =\text { Jumlah tiang dalam satu kolom } \\
\mathrm{n} & =\text { Jumlah tiang dalam satu baris } \\
\theta & =\operatorname{arc} \text { tg D/S dalam satu baris } \\
\mathrm{s} & =\text { Jarak pusat ke pusat tiang } \\
\mathrm{d} & =\text { Diameter tiang }
\end{array}
$$

\section{Metode Los Angeles Group}

$$
\eta=1-\frac{\mathrm{D}}{\mathrm{s} \cdot \mathrm{m} \cdot \mathrm{n}^{\prime}}[\mathrm{m}(\mathrm{n}-1)+\mathrm{n}(\mathrm{m}-1)+\sqrt{2}(\mathrm{n}-1)(\mathrm{m}-1)]
$$

Keterangan:

$$
\eta \quad=\text { Efisiensi kelompok tiang }
$$




$$
\begin{array}{ll}
\mathrm{m} & =\text { Jumlah tiang dalam satu kolom } \\
\mathrm{n} & =\text { Jumlah tiang dalam satu baris } \\
\mathrm{S} & =\text { Jarak pusat ke pusat tiang } \\
\mathrm{d} & \quad \text { = Diameter tiang } \\
\mathrm{n}, & =\text { Jumlah tiang }
\end{array}
$$

Setelah faktor efisiensi diperoleh, maka kapasitas kelompok izin tiang $\left(\mathrm{Q}_{\mathrm{g}}\right)$ sebesar :

Keterangan:

$$
\mathrm{Q}_{\mathrm{g}}=\eta \times \mathrm{n}^{\prime} \times \mathrm{Qu}
$$

$\mathrm{Q}_{\mathrm{g}} \quad=$ Kapasitas kelompok izin tiang

$\eta \quad=$ Effisiensi kelompok tiang

n' = Jumlah tiang

$\mathrm{Qu} \quad=$ Kapasitas dukung ultimit tiang

\section{HASIL DAN PEMBAHASAN}

Berdasarkan grafik sondir diperoleh kedalaman tiang rencana $\mathrm{h}=7,6$ meter dengan nilai kapasitas dukung pada ujung tiang $(\mathrm{qc})=100 \mathrm{~kg} / \mathrm{cm}^{2}$. Adapun data tiang bor (bored pile) adalah tiang bor dengan diameter $40 \mathrm{~cm}$, dan kedalaman 6 meter.

\section{Metode Analisis}

Dari keempat metode yang akan digunakan akan dipilih hasil perhitungan daya dukung yang paling kritis.

\section{Metode Aoki dan de Alencar}

Perhitungan metode Aoki dan de Alencar menentukan tahanan konus berdasarkan dari kedalaman 1,5 D di atas ujung tiang dan 1,5 D di bawah ujung tiang.

\begin{tabular}{|c|c|c|c|}
\hline No. & $\begin{array}{c}\text { Kedalaman } \\
(\mathrm{m})\end{array}$ & $\begin{array}{c}\mathrm{qc} \\
\left(\mathrm{kg} / \mathrm{cm}^{2}\right)\end{array}$ & Rata-rata \\
\hline 1 & 5,40 & 61 & \multirow{5}{*}{$\begin{aligned} \mathrm{q}_{\mathrm{c} 1} & =\frac{\sum \mathrm{q}_{\mathrm{c}}}{\sum \mathrm{n}}=\frac{239}{4} \\
& =59,75\end{aligned}$} \\
\hline 4 & 5,60 & 60 & \\
\hline 5 & 5,80 & 56 & \\
\hline 6 & 6,00 & 62 & \\
\hline$\Sigma=$ & 4 data & 239 & \\
\hline
\end{tabular}

1. Kedalaman $1,5 \mathrm{D}$ diatas ujung tiang

$1,5 \mathrm{D}=1,5 \times 40 \mathrm{~cm}=60 \mathrm{~cm}=0,6 \mathrm{~m}$

jumlah data $=4$ buah

Tabel 3. Tahanan Konus Rata-Rata 1,5 D Di Atas Kedalaman Ujung Tiang

Sumber : (Analisis, 2018)

\begin{tabular}{|c|c|c|c|}
\hline No. & $\begin{array}{l}\text { Kedalaman } \\
(\mathrm{m})\end{array}$ & $\begin{array}{l}\mathrm{qc} \\
\left(\mathrm{kg} / \mathrm{cm}^{2}\right)\end{array}$ & Rata-rata \\
\hline 1 & 6,40 & 70 & \multirow{5}{*}{$\mathrm{q}_{\mathrm{c} 2}=\frac{\sum \mathrm{q}_{\mathrm{c}}}{\sum \mathrm{n}}=\frac{260}{4}=65$} \\
\hline 2 & 6,60 & 65 & \\
\hline 3 & 6,20 & 63 & \\
\hline 4 & 6,00 & 62 & \\
\hline$\Sigma=$ & 4 data & 260 & \\
\hline
\end{tabular}

2. Kedalaman $1,5 \mathrm{D}$ dibawah ujung tiang $1,5 \mathrm{D}=1,5 \times 40 \mathrm{~cm}=60 \mathrm{~cm}=0,6 \mathrm{~m}$ jumlah data $=4$ buah

Tabel 4. Tahanan Konus Rata-Rata 1,5D Di Bawah Kedalaman Ujung Tiang.

3. Tahanan kerucut rata-rata

$$
\begin{aligned}
\mathrm{q}_{\mathrm{ca}} & =\frac{\mathrm{q}_{\mathrm{c} 1}+\mathrm{q}_{\mathrm{c} 2}}{2} \\
& =\frac{59,75+65}{3,5} \\
& =62,38 \mathrm{~kg} / \mathrm{cm}^{2}
\end{aligned}
$$

4. Hitung tahanan ujung tiang

Berdasarkan Tabel 3.5 nilai $\mathrm{F}_{\mathrm{b}}$ untuk bored pile adalah 3,5, maka:

$$
\begin{aligned}
\mathrm{q}_{\mathrm{b}} & =\frac{\mathrm{q}_{\mathrm{ca}}(\text { base })}{\mathrm{F}_{\mathrm{b}}}=\frac{62,38}{3,5} \\
& =17,82 \mathrm{~kg} / \mathrm{cm}^{2} \\
& =1748,28 \mathrm{kN} / \mathrm{m}^{2}
\end{aligned}
$$

5. Kuat dukung ultimit

$$
\begin{aligned}
\mathrm{A}_{\mathrm{b}} & =1 / 4 \pi(40)^{2} \\
& =1256 \mathrm{~cm}^{2} \\
& =0,1256 \mathrm{~m}^{2} \\
\mathrm{Q}_{\mathrm{u}}= & \mathrm{q}_{\mathrm{b}} \times \mathrm{A}_{\mathrm{b}} \\
\mathrm{Q}_{\mathrm{u}} & =1849,14 \times 0,1256 \\
& =219,584 \mathrm{kN}
\end{aligned}
$$

\begin{tabular}{|c|c|c|c|}
\hline No. & $\begin{array}{c}\text { Kedalaman } \\
(\mathrm{m})\end{array}$ & $\begin{array}{c}\mathrm{qc} \\
\left(\mathrm{kg} / \mathrm{cm}^{2}\right)\end{array}$ & Rata-rata \\
\hline 1 & 2,80 & 25 & \multirow{11}{*}{$\begin{aligned} \mathrm{q}_{\mathrm{cl}} & =\frac{\sum \mathrm{q}_{\mathrm{c}}}{\sum \sum \mathrm{n}}=\frac{755}{17} \\
& =44,42\end{aligned}$} \\
\hline 2 & 3,00 & 26 & \\
\hline 3 & 3,20 & 30 & \\
\hline 4 & 3,40 & 34 & \\
\hline 5 & 3,60 & 35 & \\
\hline 6 & 3,80 & 35 & \\
\hline 7 & 4,00 & 43 & \\
\hline 8 & 4,20 & 48 & \\
\hline 9 & 4,40 & 40 & \\
\hline 10 & 4,60 & 44 & \\
\hline 11 & 4,80 & 47 & \\
\hline
\end{tabular}

Pada perhitungan kapasitas pondasi bored pile dengan sondir tidak diperhitungkan kuat dukung selimut bored pile. Hal ini dikarenakan perlawanan geser tanah yang terjadi pada pondasi bored pile dianggap sangat kecil sehingga dianggap tidak ada. Untuk memperoleh kapasitas ijin tiang, maka diperlukan untuk membagi kapasitas ultimit dengan faktor aman tertentu.

$$
\begin{aligned}
\mathrm{Q}_{\mathrm{a}} & =\frac{\mathrm{Q}_{\mathrm{u}}}{2} \\
& =\frac{219,584}{2} \\
& =109,792 \mathrm{kN}
\end{aligned}
$$

\section{Metode Schmertmann dan Nottinghamm}

Schmertmann dan Nottingham mendefinisikan tahanan konus pada rata-rata $8 \mathrm{D}$ di atas ujung tiang, dan 4 D di bawah ujung tiang.

1. Kedalaman $8 \mathrm{~d}$ diatas ujung tiang $8 \mathrm{D}=8 \times 40 \mathrm{~cm}=320 \mathrm{~cm}=3,2 \mathrm{~m}$ jumlah data $=17$ buah

Tabel 5. Tahanan Konus Rata-Rata 8d Di atas Kedalaman Ujung Tiang. 


\begin{tabular}{|c|c|c|}
\hline 12 & 5,00 & 49 \\
\hline 13 & 5,20 & 60 \\
\hline 14 & 5,40 & 61 \\
\hline 15 & 5,60 & 60 \\
\hline 16 & 5,80 & 56 \\
\hline 17 & 6,00 & 62 \\
\hline$\Sigma=$ & 17 data & 755 \\
\hline
\end{tabular}

(Sumber : Analisis, 2018)

2. Kedalaman 4 d dibawah ujung tiang $4 \mathrm{D}=4 \times 40 \mathrm{~cm}=160 \mathrm{~cm}=1,6 \mathrm{~m}$ jumlah data $=9$ buah

Tabel 6. Tahanan Konus Rata-Rata 4d Di Bawah Kedalaman Ujung Tiang

\begin{tabular}{|c|c|c|c|}
\hline No. & $\begin{array}{l}\text { Kedalaman } \\
(\mathrm{m})\end{array}$ & $\begin{array}{c}\mathrm{qc} \\
\left(\mathrm{kg} / \mathrm{cm}^{2}\right)\end{array}$ & Rata-rata \\
\hline 1 & 6,00 & 62 & \multirow{10}{*}{$\mathrm{q}_{\mathrm{c} 2}=\frac{\sum \mathrm{q}_{\mathrm{c}}}{\sum \mathrm{n}}=\frac{700}{9}=77,78$} \\
\hline 2 & 6,20 & 63 & \\
\hline 3 & 6.40 & 70 & \\
\hline 4 & 6,60 & 65 & \\
\hline 5 & 6,80 & 75 & \\
\hline 6 & 7,00 & 81 & \\
\hline 7 & 7,20 & 84 & \\
\hline 8 & 7,40 & 100 & \\
\hline 9 & 7,60 & 100 & \\
\hline$\Sigma=$ & 9 data & 700 & \\
\hline
\end{tabular}

(Sumber : Analisis, 2018)

3. Tahanan kerucut rata-rata

$$
\begin{aligned}
\mathrm{q}_{\mathrm{ca}} & =1 / 2\left(\mathrm{q}_{\mathrm{c} 1}+\mathrm{q}_{\mathrm{c} 2}\right) \\
& =1 / 2(44,42+77,78) \\
& =61,10 \mathrm{~kg} / \mathrm{cm}^{2}
\end{aligned}
$$

4. Hitung tahanan ujung tiang

$$
\mathrm{f}_{\mathrm{b}} \quad=\omega \mathrm{q}_{\mathrm{ca}} \leq 150 \mathrm{~kg} / \mathrm{cm}^{2}
$$

Asumsi kondisi tanah kerikil halus, maka nilai faktor $\omega=0,5$ (Tabel 3.4)

$$
\begin{aligned}
\mathrm{f}_{\mathrm{b}} & =0,5 \times 61,10=30,547 \mathrm{~kg} / \mathrm{cm}^{2} \leq 150 \mathrm{~kg} / \mathrm{cm}^{2} . \\
\mathrm{Q}_{\mathrm{b}} & =\mathrm{A}_{\mathrm{b}} \cdot \mathrm{f}_{\mathrm{b}} \\
& =1 / 4 \pi(40)^{2} \times 30,547 \mathrm{~kg} / \mathrm{cm}^{2} \\
& =38367,516 \mathrm{~kg} \\
& =376,385 \mathrm{kN}
\end{aligned}
$$

5. Kuat dukung ultimit

$$
\begin{aligned}
& \text { Berat sendiri tiang: } \\
& \begin{aligned}
\mathrm{W}_{\mathrm{p}} & =2400 \mathrm{~kg} / \mathrm{m}^{3} \times 1 / 4 \pi(0,4)^{2} \times 6 \\
& =1809,557 \mathrm{~kg} \\
& =17,75 \mathrm{kN} \\
\mathrm{Q}_{\mathrm{u}} & =\mathrm{Q}_{\mathrm{b}}-\mathrm{W}_{\mathrm{P}} \\
& =376,385-17,75 \\
& =358,633 \mathrm{kN}
\end{aligned}
\end{aligned}
$$

\begin{tabular}{|c|c|c|c|}
\hline 1 & 6,00 & 62 & \multirow{3}{*}{$\mathrm{q}_{\mathrm{c} 2}=\frac{\sum \mathrm{q}_{\mathrm{c}}}{\sum \mathrm{n}}=\frac{195}{3}=65$} \\
\hline 2 & 6,20 & 63 & \\
\hline 3 & 6,40 & 70 & \\
\hline$\Sigma=$ & 3 data & 195 & \\
\hline
\end{tabular}

Dengan menggunakan faktor aman $\mathrm{F}=2,5$, diperoleh kapasitas ijin tiang:

$$
\begin{aligned}
\mathrm{Qu}_{\mathrm{u}} & =358,633 / 2,5 \\
& =143,453 \mathrm{kN}
\end{aligned}
$$

\section{Metode Meyerhoff}

Meyerhoff mendefinisikan tahanan konus dari kedalaman $1 \mathrm{D}$ di bawah ujung tiang, dan $4 \mathrm{D}$ di atas ujung tiang.

1. Kedalaman $1 \mathrm{~d}$ di bawah ujung tiang

$1 \mathrm{D}=1 \times 40 \mathrm{~cm}=40 \mathrm{~cm}=0,4 \mathrm{~m}$ jumlah data $=3$ buah

Tabel 7. Tahanan Konus Rata-Rata 1d Di Bawah Kedalaman Ujung Tiang

\begin{tabular}{|c|c|c|c|}
\hline No. & $\begin{array}{c}\text { Kedalaman } \\
(\mathrm{m})\end{array}$ & $\begin{array}{c}\mathrm{qc} \\
\left(\mathrm{kg} / \mathrm{cm}^{2}\right)\end{array}$ & Rata-rata \\
\hline
\end{tabular}

(Sumber : Analisis, 2018)

2. Kedalaman $4 \mathrm{~d}$ di atas ujung tiang $4 \mathrm{D}=4 \times 40 \mathrm{~cm}=160 \mathrm{~cm}=1,6 \mathrm{~m}$ jumlah data $=9$ buah

Tabel 8. Tahanan Konus Rata-Rata 4d Di Atas Kedalaman Ujung Tiang

\begin{tabular}{|c|c|c|c|}
\hline No. & $\begin{array}{c}\text { Kedalaman } \\
(\mathrm{m})\end{array}$ & $\begin{array}{c}\mathrm{qc} \\
\left(\mathrm{kg} / \mathrm{cm}^{2}\right)\end{array}$ & Rata-rata \\
\hline 1 & 4,40 & 40 & \multirow{3}{*}{} \\
\hline 2 & 4,60 & 44 & \\
\hline 3 & 4,80 & 47 & \multirow{3}{*}{$\mathrm{q}_{\mathrm{c} 2}=\frac{\sum \mathrm{q}_{\mathrm{c}}}{\sum \mathrm{n}}=\frac{474}{9}$} \\
\hline 4 & 5,00 & 49 & 52,67 \\
\hline 5 & 5,20 & 60 & \\
\hline 6 & 5,40 & 61 & \\
\hline 7 & 5,60 & 60 & \\
\hline 8 & 5,80 & 56 & \\
\hline 9 & 6,00 & 62 & \\
\hline$\Sigma=$ & 9 data & 474 & \\
\hline
\end{tabular}

(Sumber: Analisis, 2018)

3. Tahanan ujung per satuan luas

$$
\begin{aligned}
\mathrm{q}_{\mathrm{ca}} & =1 / 2\left(\mathrm{q}_{\mathrm{c} 1}+\mathrm{q}_{\mathrm{c} 2}\right) \\
& =1 / 2(65+52,67) \\
& =58,83 \mathrm{~kg} / \mathrm{cm}^{2} \\
& =5771,55 \mathrm{kN} / \mathrm{m}^{2} \\
\mathrm{~d} & =0,4 \mathrm{~m}<0,5 \mathrm{~m}, \\
\mathrm{~N} & =1 \text { untuk pasir longgar }\left(\mathrm{q}_{\mathrm{c}}<5 \mathrm{Mpa}\right) \\
\omega_{1} & =[(\mathrm{d}+0,5) / 2 \mathrm{~d}]^{\mathrm{n}} \\
& =[(0,4+0,5) / 2(0,4)]^{1} \\
& =1,125
\end{aligned}
$$

untuk $\mathrm{L}=6$ meter, dan $\mathrm{d}=0,4$ meter, sehingga

$10 \mathrm{~d}=10(0,4)$

$$
=4 \mathrm{~m}
$$

Sehingga $\mathrm{L}>10 \mathrm{~d}$, maka $\omega_{2}=1$

$\mathrm{f}_{\mathrm{b}} \quad=\omega_{1} \omega_{2} \mathrm{q}_{\mathrm{ca}}$

$$
=1,125 \times 1 \times 5771,55 \mathrm{kN} / \mathrm{m}^{2}
$$$$
=6492,99 \mathrm{kN} / \mathrm{m}^{2}
$$

Untuk tiang bor diambil nilai $\mathrm{f}_{\mathrm{b}}=50 \%$

$$
\mathrm{f}_{\mathrm{b}} \quad=50 \% \times 6588,563 \mathrm{kN} / \mathrm{m}^{2}
$$$$
=3246,50 \mathrm{kN} / \mathrm{m}^{2}
$$

4. Tahanan ujung

$$
\begin{aligned}
\mathrm{Q}_{\mathrm{b}} & =\mathrm{A}_{\mathrm{b}} \cdot \mathrm{f}_{\mathrm{b}} \\
& =1 / 4 \pi(0,4)^{2} \times 3246,50 \mathrm{kN} / \mathrm{m}^{2} \\
& =0,1256 \mathrm{~m}^{2} \times 3246,50 \mathrm{kN} / \mathrm{m}^{2} \\
& =407,97 \mathrm{kN}
\end{aligned}
$$

5. Kuat dukung ultimit

Berat sendiri tiang:

$$
\begin{aligned}
\mathrm{W}_{\mathrm{p}}= & 2400 \mathrm{~kg} / \mathrm{m}^{3} \times{ }^{1 / 4} \pi(0,4)^{2} \times 6 \\
& =1809,557 \mathrm{~kg} \\
& =17,75 \mathrm{kN} \\
\mathrm{Q}_{\mathrm{u}} & =\mathrm{Q}_{\mathrm{b}}-\mathrm{W}_{\mathrm{P}} \\
& =407,97-17,75 \\
& =390,218 \mathrm{kN}
\end{aligned}
$$

Dengan menggunakan faktor aman $\mathrm{F}=2,5$, diperoleh kapasitas ijin tiang:

$$
\begin{aligned}
\mathrm{Qu}_{\mathrm{u}} & =390,218 / 2,5 \\
& =156,09 \mathrm{kN}
\end{aligned}
$$




\section{Metode Guy Sangrelatt}

Guy Sangrelatt mendefinisikan daya dukung ijin tiang terhadap tarik dan tekan tiang.

1. Daya dukung ijin tekan tiang

Daya dukung ijin tekan tiang berdasarkan data sondir pada kedalaman $6,00 \mathrm{~m}$ di bawah permukaan tanah. Berdasarkan Gambar 2, diperoleh nilai $\mathrm{q}_{\mathrm{c}}=3 \mathrm{~kg} / \mathrm{cm}^{2}$, dan $\mathrm{T}_{\mathrm{f}}=0 \mathrm{~kg} / \mathrm{cm}$

$$
\begin{aligned}
\mathrm{d} & =40 \mathrm{~cm} \\
\mathrm{~A}_{\mathrm{p}} & =1 / 4 \pi \mathrm{d}^{2} \\
& =1 / 4 \pi(40)^{2} \\
& =1256,637 \mathrm{~cm}^{2} \\
\mathrm{~A}_{\mathrm{st}} & =\pi \mathrm{d} \\
& =\pi(40) \\
& =125,664 \mathrm{~cm} \\
\mathrm{FK}_{1} & =3 \\
\mathrm{FK}_{2} & =5 \\
\mathrm{P}_{\mathrm{a}} & =\frac{\mathrm{q}_{\mathrm{c}} \times \mathrm{A}_{\mathrm{p}}}{\mathrm{FK} 1}+\frac{\mathrm{T}_{\mathrm{F}} \times \mathrm{A}_{\mathrm{st}}}{\mathrm{FK} 2} \\
& =\frac{62 \times 1256,6373}{3}+\frac{0 \times 125,664}{5} \\
& =25970,499 \mathrm{~kg} \\
& =201,351 \mathrm{kN}
\end{aligned}
$$

Perhitungan untuk kedalaman selanjutnya dapat dilihat pada Tabel 9.

Tabel 9. Daya dukung ijin tekan tiang berdasarkan data sondir

\begin{tabular}{|c|c|c|c|c|}
\hline $\begin{array}{c}\text { Kedalaman } \\
(\mathrm{m})\end{array}$ & $\begin{array}{c}\mathrm{q}_{\mathrm{c}} \\
\left(\mathrm{kg} / \mathrm{cm}^{2}\right)\end{array}$ & $\begin{array}{c}\mathrm{T}_{\mathrm{f}} \\
(\mathrm{kg} / \mathrm{cm})\end{array}$ & $\begin{array}{c}\mathrm{P}_{\text {all }} \\
(\mathrm{kg})\end{array}$ & $\begin{array}{c}\mathrm{P}_{\text {all }} \\
(\mathrm{kN})\end{array}$ \\
\hline 1 & 3 & 0 & 1256,637 & 12,328 \\
\hline 2 & 4 & 0,18 & 1680,040 & 16,481 \\
\hline 3 & 26 & 0 & 10890,855 & 106,839 \\
\hline 4 & 43 & 0 & 18011,798 & 176,696 \\
\hline 5 & 49 & 0 & 20525,072 & 201,351 \\
\hline 6 & 62 & 0 & 25970,499 & 254,771 \\
\hline 6,2 & 63 & 0 & 26389,378 & 258,880 \\
\hline 6,4 & 70 & 0 & 29321,531 & 287,644 \\
\hline 6,6 & 65 & 0 & 27227,136 & 267,098 \\
\hline 6,8 & 75 & 0 & 31415,927 & 308,190 \\
\hline 7 & 81 & 0 & 33929,201 & 332,845 \\
\hline 7,2 & 84 & 0,18 & 35190,362 & 345,217 \\
\hline 7,4 & 100 & 0,54 & 41901,474 & 411,053 \\
\hline 7,6 & 100 & 0,9 & 41910,522 & 411,142 \\
\hline
\end{tabular}

(Sumber : Analisis, 2018)

\section{Daya dukung ijin tarik tiang}

Daya dukung ijin tekan tiang berdasarkan data sondir pada kedalaman $1,00 \mathrm{~m}$ di bawah permukaan tanah: Berdasarkan Gambar 2, diperoleh nilai $T_{\mathrm{f}}=0 \mathrm{~kg} / \mathrm{cm}$ rencana, $d=40 \mathrm{~cm}$

$$
\begin{aligned}
\mathrm{A}_{\mathrm{st}} & =\pi \mathrm{d} \\
& =\pi(40) \\
& =125,664 \mathrm{~cm} \\
\mathrm{FK}_{2} & =5 \\
\mathrm{~W}_{\mathrm{p}} & =2400 \mathrm{~kg} / \mathrm{m}^{3} \times 1 / 4 \pi \times 0,4 \times 0,4 \times 6 \\
& =1809,557 \mathrm{~kg} \\
\mathrm{P}_{\mathrm{ta}} & =\frac{\mathrm{T}_{\mathrm{F}} \times \mathrm{A}_{\mathrm{st}} \times 0,70}{\mathrm{FK} 2}+\mathrm{W}_{\mathrm{p}} \\
& =\frac{0 \times 125,664 \times 0,70}{5}+1809,557 \\
& =1809,557 \mathrm{~kg} \\
& =17,752 \mathrm{Kn}
\end{aligned}
$$

Perhitungan untuk kedalaman selanjutnya dapat dilihat pada Tabel 10 .

Tabel 10. Daya dukung ijin tarik tiang berdasarkan data sondir

\begin{tabular}{|c|c|c|c|c|}
\hline $\begin{array}{c}\text { Kedalaman } \\
(\mathrm{m})\end{array}$ & $\begin{array}{c}\mathrm{T}_{\mathrm{F}} \\
\left(\mathrm{kg} / \mathrm{cm}^{2}\right)\end{array}$ & $\begin{array}{c}\mathrm{W}_{\mathrm{p}} \\
(\mathrm{kg})\end{array}$ & $\begin{array}{c}\mathrm{P}_{\text {all }} \\
(\mathrm{kg})\end{array}$ & $\begin{array}{c}\mathrm{P}_{\text {all }} \\
(\mathrm{kN})\end{array}$ \\
\hline 1 & 0 & 301,593 & 301,593 & 2,959 \\
\hline 2 & 0,18 & 603,186 & 606,353 & 5,948 \\
\hline 3 & 0 & 904,779 & 904,779 & 8,876 \\
\hline 4 & 0 & 1206,372 & 1206,372 & 11,835 \\
\hline 5 & 0 & 1507,964 & 1507,964 & 14,793 \\
\hline 6 & 0 & 1809,557 & 1809,557 & 17,752 \\
\hline 6,2 & 0 & 1869,876 & 1869,876 & 18,343 \\
\hline 6,4 & 0 & 1930,195 & 1930,195 & 18,935 \\
\hline 6,6 & 0 & 1990,513 & 1990,513 & 19,527 \\
\hline 6,8 & 0 & 2050,832 & 2050,832 & 20,119 \\
\hline 7 & 0 & 2111,150 & 2111,150 & 20,710 \\
\hline 7,2 & 0,18 & 2171,469 & 2174,636 & 21,333 \\
\hline 7,4 & 0,54 & 2231,787 & 2241,288 & 21,987 \\
\hline 7,6 & 0,9 & 2292,106 & 2307,940 & 22,641 \\
\hline
\end{tabular}

\section{Kapasitas Dukung Kelompok Tiang}

Kapasitas daya dukung tiang pancang kelompok dihitung berdasarkan faktor efisiensi. Kelompok tiang yang akan dianalisis adalah data-data sebagai berikut: jumlah tiang dalam satu kolom $(\mathrm{m}) \quad=4$ buah jumlah tiang dalam satu baris (n) $=4$ buah jarak tiang ke tiang lainnya $\quad=150 \mathrm{~cm}$ diameter tiang $=40 \mathrm{~cm}$ kedalaman tiang $\quad=6$ meter

\section{Metode Converse - Labarre} $\eta=1-\theta\left[\frac{(\mathrm{n}-1) \mathrm{m}+(\mathrm{m}-1) \mathrm{n}}{90 \cdot \mathrm{m} \cdot \mathrm{n}}\right]$

direncanakan $: \mathrm{m} \quad=$

$$
\mathrm{n}=4
$$$$
\text { d } \quad=40 \mathrm{~cm}
$$$$
\mathrm{s} \quad=150 \mathrm{~cm}
$$$$
\theta \quad=\operatorname{arctg} \mathrm{d} / \mathrm{s}=0,26
$$

maka $: \eta$

$$
\begin{aligned}
& =1-0,26\left[\frac{(4-1) 4+(4-1) 4}{90.4 .4}\right\rfloor \\
& =0,999
\end{aligned}
$$

\section{Metode Los Angeles Group}

$$
\begin{aligned}
& \eta=1-\frac{\mathrm{D}}{\mathrm{s} \cdot \mathrm{m} \cdot \mathrm{n}},[\mathrm{m}(\mathrm{n}-1)+\mathrm{n}(\mathrm{m}-1)+\sqrt{2}(\mathrm{n}-1)(\mathrm{m}-1)] \\
& \text { dimana }: \mathrm{m} \quad=4 \\
& \mathrm{~d} \quad=40 \mathrm{~cm} \\
& \mathrm{~s} \quad=150 \mathrm{~cm} \\
& \mathrm{n}^{\prime}=16 \\
& \text { maka }: \eta \quad=1-\frac{40}{150.4 \cdot 16}[4(4-1)+4(4-1)+\sqrt{2}(4-1)(4-1)] \\
& =0,847
\end{aligned}
$$

\section{Daya dukung kelompok tiang}

Masing-masing nilai kapasitas dukung dari perhitungan empat metode yang telah dihitung diatas, dikalikan dengan nilai efisiensi dan jumlah tiang seperti yang terlihat pada Tabel 11 dan Gambar 3.

Tabel 11. Rekapitulasi hasil perhitungan daya dukung kelompok tiang

\begin{tabular}{|l|c|c|}
\hline \multicolumn{1}{|c|}{ Metode } & $\begin{array}{c}\text { Converse } \\
- \text { Labarre } \\
(\mathrm{kN})\end{array}$ & $\begin{array}{c}\text { Los } \\
\text { Angeles } \\
\text { Group } \\
(\mathrm{kN})\end{array}$ \\
\hline Aoki \& de Alencar & 1794,044 & 1487,845 \\
\hline Schmertmann \& Nottingham & 2285,284 & 1944,003 \\
\hline Meyerhoff & 2486,548 & 2115,211 \\
\hline Guy Sangrelatt & 3490,422 & 2969,168 \\
\hline (Sumber: Analisis, 2018) & &
\end{tabular}




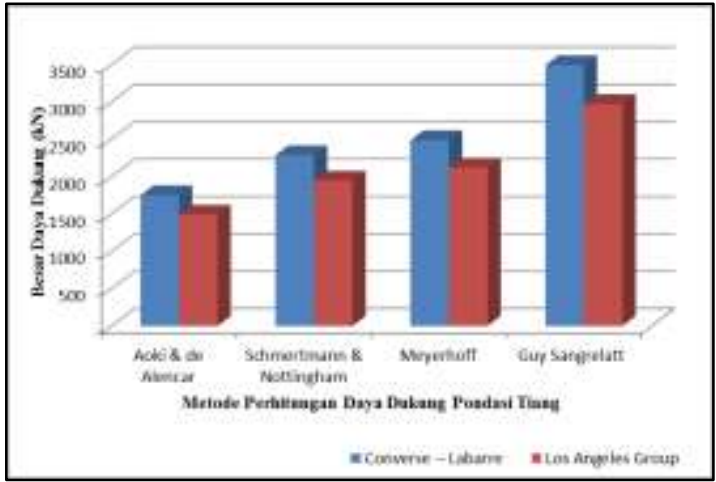

Gambar 3. Grafik perbandingan daya dukung kelompok tiang (Sumber: Analisis, 2018)

Dapat dilihat bahwa nilai daya dukung terendah adalah Metode Aoki dan de Alencar yaitu sebesar 1487,845 kN, dan tertinggi adalah Metode Guy Sangrelatt yaitu sebesar 2969,168 kN. Adapun jika diambil rata-rata untuk efisiensi menurut Converse-Labarre diperoleh nilai sebesar 2528,05 kN dan menurut Los Angeles Group adalah sebesar $2150,515 \mathrm{kN}$.

\section{Analisis Daya Dukung Pondasi Bored Pile terhadap Beban Struktur Menara}

Dari tabel pembebanan yang diperoleh dari pihak kontraktor proyek, maka diambil beban maksimum khususnya beban vertikal dari struktur menara transmisi seperti terlihat pada Tabel 12.

Tabel 12. Pembebanan maksimum struktur menara transmisi

\begin{tabular}{|c|c|c|c|}
\hline $\begin{array}{c}\text { Tipe } \\
\text { Pembebanan*) }\end{array}$ & Kondisi & $\begin{array}{c}\text { Support Reaction } \\
(\text { Max })\end{array}$ & $\begin{array}{c}\text { Force }-Z \\
(\mathrm{kN})\end{array}$ \\
\hline \multirow{4}{*}{ Vertical } & Normal & Compression & 536,727 \\
\cline { 3 - 4 } & Broken & Uplift & 399,581 \\
\cline { 2 - 4 } & Compression & 424,313 \\
\cline { 3 - 4 } & Uplift & 282,435 \\
\hline
\end{tabular}

(Sumber : PT. Bukaka Teknik Utama, 2016)

Faktor beban overload (darurat) yang disarankan oleh PT. Bukaka Teknik Utama adalah 1,2. Dengan demikian diperoleh beban terfaktor seperti terlihat pada Tabel 13.

Tabel 13. Pembebanan terfaktor struktur menara transmisi

\begin{tabular}{|l|c|c|c|}
\hline $\begin{array}{l}\text { Tipe } \\
\text { Pembebanan*) }\end{array}$ & Kondisi & $\begin{array}{c}\text { Support Reaction } \\
(\text { Max })\end{array}$ & $\begin{array}{c}\text { Force }-Z \\
(\mathrm{kN})\end{array}$ \\
\hline \multirow{4}{*}{ Vertical } & \multirow{2}{*}{ Normal } & Compression & 644,072 \\
\cline { 3 - 4 } & \multirow{2}{*}{ Broken } & Uplift & 479,497 \\
\cline { 3 - 4 } & Compression & 509,176 \\
\hline
\end{tabular}

(Sumber : Analisis, 2018)

Dapat dilihat dari Tabel 13 bahwa kapasitas beban terfaktor menara transmisi sebesar 644,072 kN lebih kecil daripada daya dukung ijin rencana sebesar $1573,678 \mathrm{kN}$ sehingga langkah selanjutnya adalah meninjau apakah pondasi tiang bor dapat menahan gaya tarik ke atas (uplift) dari struktur menara.

\section{Tinjauan tiang menahan gaya tarik ke atas (uplift)}

Untuk meninjau gaya tarik ke atas, digunakan metode Guy Sangrelat yang dikombinasikan dengan metode Meyerhoff. Berdasarkan Tabel 10 dapat dilihat hasil Pall (daya dukung tiang tunggal terhadap tarik) sehingga perlu dikalikan dengan jumlah tiang dan faktor efisiensi. Sehingga diperoleh untuk nilai daya dukung tiang kelompok adalah sebagaimana terlihat pada Tabel 14.

Tabel. 14. Perhitungan efisiensi daya dukung ijin tiang

\begin{tabular}{|l|l|l|l|l|l|l|}
\hline Kedalaman & TF & Wp & Pall & Pall & Qg1 & Qg2
\end{tabular}

\begin{tabular}{|c|c|c|c|c|c|c|}
\hline $\mathrm{m}$ & $\mathrm{kg} / \mathrm{cm} 2$ & $\mathrm{~kg}$ & $\mathrm{~kg}$ & $\mathrm{kN}$ & $\mathrm{kN}$ & $\mathrm{kN}$ \\
\hline 6 & 0 & 1809,557 & 1809,557 & 17,752 & 282,794 & 240,562 \\
\hline 6,2 & 0 & 1869,876 & 1869,876 & 18,343 & 292,221 & 248,581 \\
\hline 6,4 & 0 & 1930,195 & 1930,195 & 18,935 & 301,647 & 256,600 \\
\hline 6,6 & 0 & 1990,513 & 1990,513 & 19,527 & 311,074 & 264,619 \\
\hline 6,8 & 0 & 2050,832 & 2050,832 & 20,119 & 320,500 & 272,637 \\
\hline 7 & 0 & $2111,1502111,150$ & 20,710 & 329,927 & 280,656 \\
\hline 7,2 & 0,18 & 2171,469 & 2174,636 & 21,333 & 339,848 & 289,096 \\
\hline 7,4 & 0,54 & $2231,7872241,288$ & 21,987 & 350,265 & 297,957 \\
\hline 7,6 & 0,9 & 2292,106 & 2307,940 & 22,641 & 360,681 & 306,817 \\
\hline
\end{tabular}

(Sumber : Analisis, 2018)

Dari Tabel 14 terlihat bahwa tidak ada kedalaman yang memenuhi kapasitas untuk beban uplift menara transmisi sebesar 479,497 kN. Maka perlu dipertimbangkan untuk menambah jumlah tiang, namun masih dengan diameter yang sama yaitu $40 \mathrm{~cm}$. Dicoba jumlah tiang rencana adalah sebanyak 25 buah secara simetris 5 untuk arah $\mathrm{x}$ dan 5 untuk arah y dan kedalaman yang digunakan adalah 7,6 m. Dengan cara yang sama, maka diperoleh nilai daya dukung ijin tarik tiang bor adalah sebagai berikut:

1. Metode Converse - Labarre

$$
\begin{aligned}
\eta=1-\theta\left\lfloor\frac{(\mathrm{n}-1) \mathrm{m}+(\mathrm{m}-1) \mathrm{n}}{90 \cdot \mathrm{m} \cdot \mathrm{n}}\right\rfloor & \\
\text { direncanakan }: \mathrm{m} & =5 \\
\mathrm{n} & =5 \\
\mathrm{~d} & =40 \mathrm{~cm} \\
\mathrm{~s} & =150 \mathrm{~cm} \\
\theta & =\operatorname{arctg~d} / \mathrm{s} \\
& =0,26 \\
\text { maka } & : \eta \quad \\
& =1-0,26\left\lfloor\frac{(5-1) 5+(5-1) 5}{90.5 .5}\right] \\
& =0,995
\end{aligned}
$$

Diambil kedalaman 7,6 m, sehingga diperoleh :

$$
\begin{aligned}
\mathrm{d} & =40 \mathrm{~cm} \\
\mathrm{~A}_{\mathrm{st}} & =\pi \mathrm{d} \\
& =\pi(40) \\
& =125,664 \mathrm{~cm} \\
\mathrm{FK}_{2} & =5 \\
\mathrm{~W}_{\mathrm{p}} & =2400 \mathrm{~kg} / \mathrm{m}^{3} \times 0,4 \times 0,4 \times 7,6 \\
& =2292,106 \mathrm{~kg} \\
\mathrm{P}_{\mathrm{a}} & =\frac{\mathrm{T}_{\mathrm{F}} \times \mathrm{A}_{\mathrm{st}} \times 0,70}{\mathrm{FK} 2}+\mathrm{W}_{\mathrm{p}} \\
& =\frac{0 \times 125,664 \times 0,70}{5}+2292,106 \\
& =2307,940 \mathrm{~kg} \\
& =22,641 \mathrm{kN}
\end{aligned}
$$

Maka nilai daya dukung kelompok tiang adalah:

$$
\begin{aligned}
\mathrm{Q}_{\mathrm{g}} & =\eta \times \mathrm{n}{ }^{\prime} \times \mathrm{Qu} \\
& =0,999 \times 25 \times 22,641 \\
& =563,400 \mathrm{kN}
\end{aligned}
$$

2. Metode Los Angeles Group

$$
\begin{aligned}
\eta=1-\frac{D}{s . m \cdot n \prime} & {[\mathrm{m}(\mathrm{n}-1)+\mathrm{n}(\mathrm{m}-1)+\sqrt{2}(\mathrm{n}-1)(\mathrm{m}-1)] } \\
\text { dimana: } \mathrm{m} & =5 \\
\mathrm{n} & =5 \\
\mathrm{~d} & =40 \mathrm{~cm}
\end{aligned}
$$




$$
\begin{aligned}
\mathrm{s} & =150 \mathrm{~cm} \\
\mathrm{n}, & =25 \\
\text { maka : } \eta & =1-\frac{40}{150.5 .25}[5(5-1)+5(5-1)+\sqrt{ } 2(5-1)(5-1)] \\
& =0,866
\end{aligned}
$$

Maka nilai daya dukung kelompok tiang adalah:

$$
\begin{aligned}
\mathrm{Q}_{\mathrm{g}} & =\eta \times \mathrm{n}^{\prime} \times \mathrm{Qu} \\
& =0,866 \times 25 \times 22,641 \\
& =490,399 \mathrm{kN}
\end{aligned}
$$

Sehingga diperoleh dimensi tiang bor adalah: jumlah tiang dalam satu kolom $(\mathrm{m})=5$ buah jumlah tiang dalam satu baris $(\mathrm{n})=5$ buah jarak tiang ke tiang lainnya $\quad=150 \mathrm{~cm}$ diameter tiang $\quad=40 \mathrm{~cm}$ kedalaman tiang $\quad=7,6$ meter

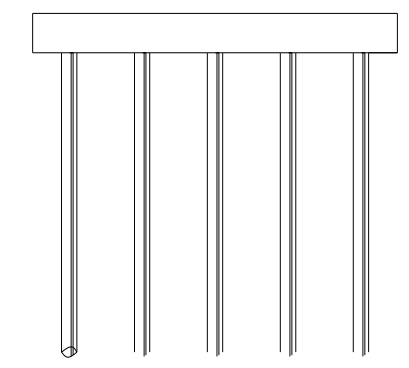

Gambar 4. Dimensi kelompok tiang bor (Sumber: Analisis, 2018)

Dengan dimensi tersebut, maka diambil nilai efisiensi Metode Los Angeles Group yang paling minimum sebesar 490,399 $\mathrm{kN}$ memenuhi untuk menahan beban uplift menara sebesar 479,497 kN.

\section{Pembahasan}

Dari perhitungan daya dukung pondasi bored pile menggunakan 4 macam metode dan untuk efisiensi kelompok tiang menggunakan 2 metode diperoleh hasil untuk diameter $40 \mathrm{~cm}$, kedalaman 6 meter, dan jumlah tiang sebanyak 16 buah adalah untuk Metode Aoki dan de Alencar diperoleh daya dukung sebesar 1794,044 kN untuk efisiensi Converse-Labarre dan 1487,845 kN untuk efisiensi Los Angeles Group. Lalu untuk Metode Schmertmann and Nottingham diperoleh nilai daya dukung sebesar 2285,284 kN untuk efisiensi ConverseLabarre dan 1944,003 kN untuk efisiensi Los Angeles Group. Selanjutnya untuk Metode Meyerhoff diperoleh nilai daya dukung sebesar 2486,548 $\mathrm{kN}$ untuk efisiensi Converse-Labarre dan 2115,211 kN untuk efisiensi Los Angeles Group. Terakhir untuk Metode Guy Sangrelatt diperoleh nilai daya dukung sebesar $3490,422 \mathrm{kN}$ untuk efisiensi Converse-Labarre dan 2969,168 kN untuk efisiensi Los Angeles Group. Dapat diihat bahwa nilai yang paling optimis atau yang terkecil untuk digunakan adalah Metode Aoki dan de Alencar, dan untuk efisiensi yang terkecil adalah Metode Los Angeles Group.

Dalam perencanaannya, menara transmisi juga harus ditinjau terhadap gaya tarik ke atas (uplift).

Berdasarkan hasil perhitungan daya dukung ijin tarik metode Guy Sangrelatt, diperoleh nilai daya dukung pondasi bored pile untuk dimensi dan kedalaman pondasi yang sama yaitu sebesar 282,794 kN untuk efisiensi Converse-Labarre dan 240,562 kN untuk efisiensi Los Angeles Group, sementara beban uplift menara transmisi jauh lebih besar yaitu sebesar 479,497 kN kondisi normal. Maka dilakukan pendimensian ulang untuk bored pile yaitu dengan menambah jumlah tiang bor menjadi 25 buah, dan menambah kedalaman tiang bor sedalam 7,6 meter dengan diameter bored pile tetap yaitu $40 \mathrm{~cm}$. Sehingga, untuk dimensi tersebut diperoleh kenaikan yang cukup signifikan untuk daya dukung pondasi sebesar $563,400 \mathrm{kN}$ untuk efisiensi Converse-Labarre dan 490,399 kN untuk efisiensi Los Angeles Group. Hal ini memenuhi untuk menahan beban uplift menara transmisi, serta memenuhi pula untuk beban compression menara transmisi.

\section{KESIMPULAN}

Dari hasil perhitungan diperoleh kesimpulan daya dukung pondasi bored pile untuk menara transmisi adalah mengenai Metode Aoki dan de Alencar lebih kritis dan paling minimum dari ketiga metode lainnya, dikarenakan banyak dipengaruhi oleh faktor empiris dalam perhitungan sehingga menghasilkan nilai terkecil daya dukung pondasi bored pile, yaitu sebesar 1487,845 kN untuk menahan beban compression menara transmisi, selanjutnya perhitungan daya dukung pondasi bored pile memenuhi untuk menahan beban compression, namun tidak memenuhi untuk menahan beban uplift. Maka dilakukan perencanaan ulang dengan cara menambah jumlah tiang dan menambah kedalaman tiang rencana, sehingga daya dukung pondasi bored pile yang diperlukan adalah sebesar $563,400 \mathrm{kN}$ untuk efisiensi Converse-Labarre dan 490,399 kN untuk efisiensi Los Angeles Group. Dari hasil tersebut adalah digunakan nilai yang terkecil agar lebih aman.

\section{DAFTAR PUSTAKA}

[1]Bowless JE. 1991. Analisa dan Desain Pondasi, Edisi Keempat Jilid 1. Jakarta: Erlangga.

[2]Das BM, Endah N, Mochtar IB, 1995. Mekanika Tanah (Prinsip-Prinsip Rekayasa Geoteknis) Jilid 1. Jakarta: Erlangga.

[3]Fadila S. 2004. Analisa Desain Struktur Dan Pondasi Menara Pemancar Tipe "Self Supporting Tower" Di Kota Palembang. Jurnal Teknik Sipil dan Lingkungan Universitas Sriwijaya Vol. 2. No. 4: 682 - 691.

[4]Guntoro H. 2009. Menara Listrik (Tower Listrik). http://dunia-

listrik.blogspot.co.id/2009/01/menara-listriktower-listrik.html. (diakses 28 Februari 2018).

[5]Hardiyatmo HC. 2014. Analisis dan Perancangan Pondasi I. Edisi Ketiga. Yogyakarta: Gadjah Mada University Press.

[6]Hardiyatmo HC. 2015. Analisis dan Perancangan Pondasi II. Edisi Ketiga. Yogyakarta: Gadjah Mada University Press.

[7]Harianti E, dan Pamungkas A. 2013. Desain Pondasi Tahan Gempa. Yogyakarta: Andi. 